Jurnal Geocelebes Vol. 3 No. 2, Oktober 2019, 66 - 74

\title{
IDENTIFIKASI BATUAN BAWAH PERMUKAAN DAERAH LONGSOR KELURAHAN KAMBO KOTA PALOPO MENGGUNAKAN METODE GEOLISTRIK KONFIGURASI DIPOLE-DIPOLE
}

\author{
Aryadi Nurfalaq*, Andi Jumardi \\ Program Studi Informatika Universitas Cokroaminoto Palopo \\ *Penulis koresponden. Alamat email: aryadinurfalaq@yahoo.co.id
}

\begin{abstract}
Abstrak
Penelitian ini bertujuan untuk mengidentifikasi batuan bawah permukaan daerah longsor di Kelurahan Kambo berdasarkan data resistivitasnya. Dalam penelitian ini dilakukan beberapa tahapan penelitian yaitu pembuatan peta kemiringan lereng menggunakan citra SRTM, Survey lapangan untuk pemetaan daerah titik longsor dan survey geolistrik konfigurasi dipole-dipole untuk mengetahui batuan bawah permukaan. Dari hasil penelitian diperoleh bahwa lokasi penelitian memiliki kemiringan lereng landai-curam. Di beberapa titik terdapat longsoran berupa longsor rayapan dan translasi. Batuan bawah permukaan terdiri dari batuan nilai resistivitas 9,5 - 105 Ohm.m berada pada permukaan hingga kedalaman $10 \mathrm{~m}$. Lapisan ini merupakan lapisan batuan berupa lempung hasil pelapukan batuan basal, kenampakan lapangan berwarna cokelat. Lapisan di bawahnya merupakan lapisan batuan yang ditafsirkan sebagai basal yang memiliki nilai tahanan jenis $105-2571$ Ohm.m. Batas antara kedua lapisan ini merupakan bidang gelincir longsor dengan nilai resistivitas $233 \mathrm{Ohm}$.m. Jenis longsor yang dihasilkan dari kondisi di Kelurahan Kambo adalah tipe translasi.
\end{abstract}

Kata Kunci: geolistrik; Kambo; longsor.

\begin{abstract}
This study aims to identify subsurface rocks landslides area in Kambo Village based on the resistivity data. In this study several stages of research were carried out, namely making slope maps using SRTM imagery, field surveys for landslide point mapping and dipole-dipole configuration geoelectric survey to determine subsurface rocks. Based on the results of the study it was found that the study location had a sloping-steep slope. At some point there are avalanches in the form of crawled and translucent landslides. The subsurface rocks consist of rock resistivity values $9.5-105 \mathrm{Ohm} . \mathrm{m}$ located on the surface to a depth of $10 \mathrm{~m}$. This layer is a layer of rock in the form of weathering clay from basalt rock, field appearance is a brown. The bottom layer is a layer of rock which is interpreted as basalt which has a resistivity value of $105-2571 \mathrm{Ohm} . \mathrm{m}$. The boundary between these two layers is the slip surface with the value of resistivity $233 \mathrm{Ohm} . \mathrm{m}$. The type of landslide that resulted from conditions in Kambo Village is a translational type.
\end{abstract}

Keywords: geoelectric; Kambo; landslide. 


\section{Pendahuluan}

Kota Palopo merupakan salah satu daerah yang memiliki potensi tinggi terjadinya bencana longsor. Berdasarkan peta perkiraan wilayah terjadinya gerakan tanah pada bulan Mei 2017 Provinsi Selatan Kota Palopo merupakan daerah potensi terjadinya gerakan tanah dalam kategori Tinggi (Kementerian ESDM, 2017). Berdasarkan data Badan Penanggulangan Bencana Daerah (BPBD) Kota Palopo (Redaksi Palopo Pos, 2016) menyatakan bahwa untuk wilayah rawan longsor di Kota Palopo terdapat di 3 (tiga) kecamatan, yakni Kecamatan Wara Barat, Kecamatan Sendana, dan juga Kecamatan Mungkajang, dimana wilayahnya berada di Latuppa, Kambo, Lebang, Battang, Sampoddo, dan Purangi. Salah satu kejadian longsor yang terjadi di Kelurahan Kambo terjadi pada tanggal 25 Oktober 2016 yang mengakibatkan robohnya talud jalan dan menimpa satu rumah warga (Redaksi Palopo Pos, 2016). Salah satu rumah warga Kambo terkena longsor sehingga rumah menjadi amblas (Padli dkk., 2017). Selain itu, metode geolistrik digunakan untuk mengidentifikasi bidang gelincir longsor di Kecamatan Mungkajang (Manrulu \& Nurfalaq, 2017).

Ada beberapa faktor yang menentukan tingkat kerentanan suatu wilayah terhadap longsor diantara kemiringan lereng dan kondisi geologi suatu daerah.

\section{Kemiringan Lereng}

Semakin curam lereng dan panjang maka kecepatan aliran permukaan meningkat sehingga daya angkutnya juga meningkat. Semakin panjang lereng maka volume air yang mengalir semakin besar pula sehingga kecepatan aliran juga semakin besar dan benda yang bisa diangkut akan lebih banyak (Martono, 2004). Peta kemiringan lereng dapat buat dengan memanfaatkan Citra Shuttle Radar Topography Mission (SRTM) resolusi 30 $m$ yang dapat digunakan untuk mengidentifikasi daerah longsor di Wara Barat sepanjang jalan poros Palopo-Toraja (Manrulu \& Nurfalaq, 2018).

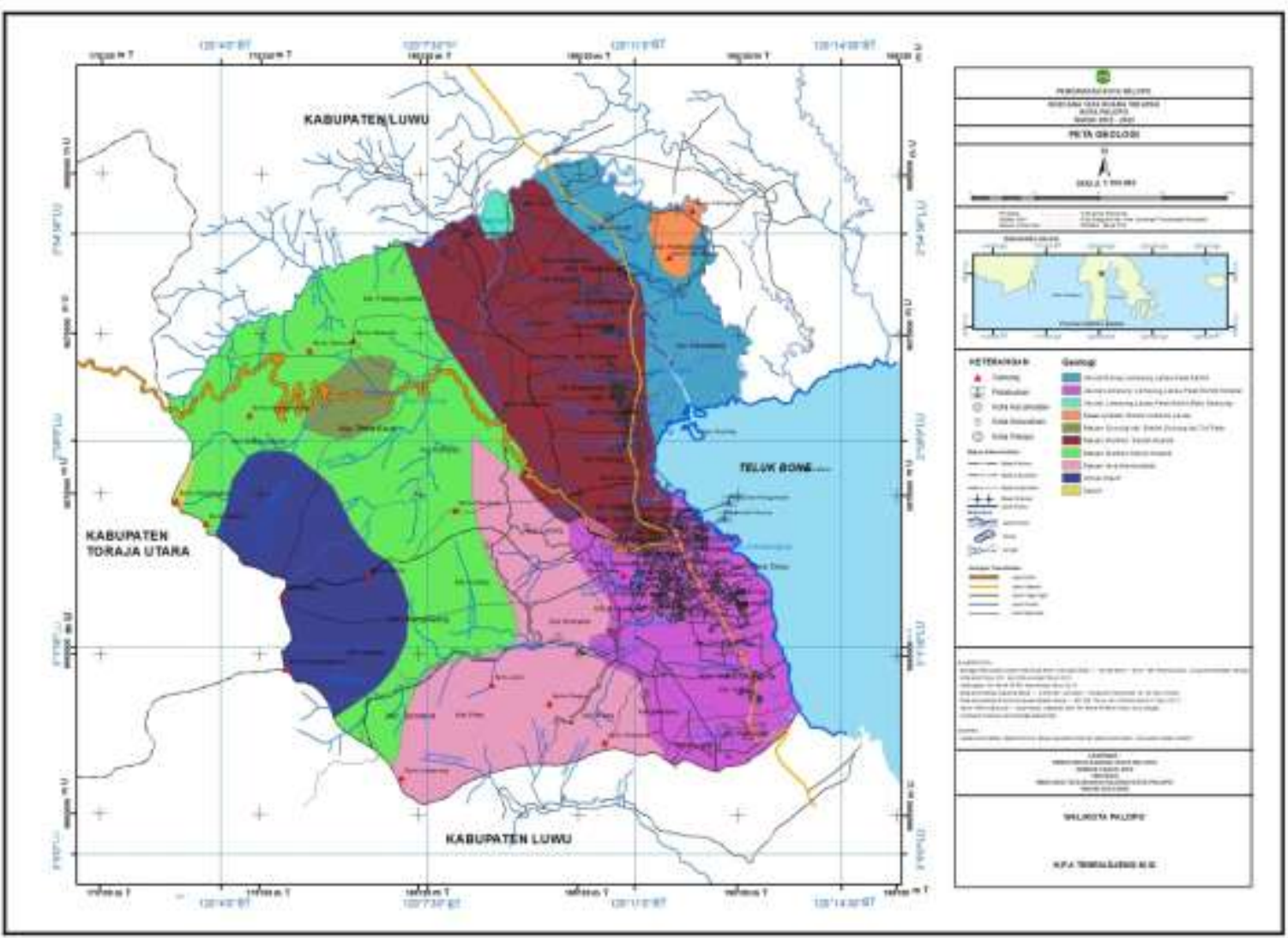

Gambar 1. Peta Geologi Kota Palopo (Pemerintah Kota Palopo, 2011). 
Ada pun pembobotan kelas kemiringan lereng mengikuti tabel 1 , berikut ini:

Tabel 1. Klasifikasi Pembobotan Parameter Kemiringan Lereng (Syafri dkk., 2015)

\begin{tabular}{ccc}
\hline No & $\begin{array}{c}\text { Kemiringan Lereng } \\
(\% / d e r a j a t)\end{array}$ & Kelas \\
\hline 1 & $<8 /(0-5)$ & Datar \\
\hline 2 & $8-15 /(5-7,5)$ & Landai \\
\hline 3 & $15-25 /(7,5-13,5)$ & Agak curam \\
\hline 4 & $25-45 /(13,5-25,5)$ & Curam \\
\hline 5 & $>45 /(>25,5)$ & Sangat curam \\
\hline
\end{tabular}

\section{Kondisi Geologi Kota Palopo}

Berdasarkan Peta Geologi Kota Palopo (Gambar 1), struktur batuan di Kota Palopo pada umumnya terdiri dari beberapa jenis batuan beku, batuan metamorf dan batuan vulkanik serta endapan alluvial yang mendominasi hampir di seluruh wilayah Kota Palopo.

Batuan beku Kota Palopo secara umum terdiri dari intrusi batuan beku granit dan gabro serta beberapa intrusi kecil lainnya. Kemudian dijumpai pula batuan beku yang merupakan jejak aliran lava yang telah membeku yang bersusunan basaltik hingga andesitik. Batuan sedimen Kota Palopo didominasi oleh batugamping, batupasir, dan konglomerat, sedangkan batuan metamorf yang dijumpai meliputi batuan metasedimen. Batuan vulkanik yang dijumpai terdiri dari tufa dan breksi vulkanik. Sedangkan endapan-endapan alluvial terdiri dari material-material bersusunan kerakal, kerikil, pasir hingga lempung. Jenis batuan lainnya yang merupakan pelapukan bahan pembentuk tanah yang mempunyai kandungan potensial di Kota Palopo antara lain batugamping dan marmer dengan lokasi penyebarannya di Kecamatan Telluwanua, batuan granit dan granodiorit untuk bahan bangunan lantai rumah, batu hias dinding dan sebagainya serta untuk pengerasan jalan (aggregat). Lokasi penyebarannya di Kecamatan Wara dan Wara Selatan, batusabak, filit, kuarsit, batugamping, dan batulanau, terdapat di Kecamatan Wara,
Wara Utara dan Bagian Barat Kota Palopo (Pemerintah Kota Palopo, 2011).

Berdasarkan peta geologi yang diterbitkan oleh Pemerintah Kota Palopo (2011), jenis batuan penyusun daerah Kota Palopo berdasarkan umur pembentukannya yang diurut dari batuan yang termuda hingga yang tertua, yaitu;

a. Kelompok endapan alluvial (termasuk didalamnya endapan Qal atau terumbu lokal) yang termasuk di dalamnya endapan alluvial berupa kerakal, kerikil, pasir dan batu, serta terumbu koral yang tersebar di sepanjang pantai dan alur aliran Sungai Latuppa.

b. Batuan Tmb; terdiri dari napal dan sisipan batugamping setempat-tempat, mengandung batupasir gampingan, konglomerat dan breksi. Selain itu terdapat beberapa kelompok intrusi batuan beku yang terdiri dari granit dan gabro. Batuan granit ini dijumpai pada Kecamatan Wara dan Kecamatan Telluwanua.

c. Batuan Tol, yaitu kelompok batuan hasil pembekuan aliran lava yang bersusun basaltik hingga andesitik, kemudian breksi vulkanik, batupasir dan batulanau, serta batuan setempattempat mengandung fieldsphatoid. Batuan ini tersusun di bagian selatan Kota Palopo dan banyak tersebar di daerah Kecamatan Wara Selatan.

d. Batuan Tet, yaitu terdiri dari serpih, batugamping dan batupasir dengan sisipan konglomerat. Kelompok batuan ini terdapat di Kecamatan Wara dan Kecamatan Telluwanua.

e. Batuan TKI, yaitu terdiri dari batuanbatuan yang mengalami metamorfisme antara lain serpih, filit, rijang, marmer, kuarsit dan beberapa bagian di utara Kota Palopo masuk dalam wilayah Kecamatan Wara dan Kecamatan Wara Selatan.

Lokasi penelitian terletak di lereng Bukit Kambo dimana batuan penyusun berupa 
lempung hasil pelapukan batuan basal. Kenampakan lapangan berwarna cokelat.

\section{Geolistrik Konfigurasi Dipole-dipole}

Pendekatan yang lebih mudah dipahami mengenai kajian gejala kelistrikan bumi adalah dengan menganggap bumi sebagai medium homogen (jenis litologi sama) dan bersifat isotropis (diukur dari berbagai arah akan memberikan harga yang sama). Medan listrik dari sumber titik di dalam bumi merupakan simetri bola. Pada prinsipnya metode geolistrik menggunakan penginjeksian arus listrik melalui sepasang elektroda arus $C_{1}$ dan $C_{2}$ yang ditancapkan ke tanah. Kemudian sepasang elektroda $P_{1}$ dan $P_{2}$ lainnya digunakan untuk mengukur potensial yang ditimbulkan oleh injeksi arus tersebut yang juga ditempatkan di permukaan bumi. Dengan mengetahui besarnya arus yang diinjeksikan dan potensial yang terukur maka tahanan jenis batuan bawah permukaan dapat diketahui (Manrulu \& Nurfalaq, 2017).

$$
\rho_{\alpha}=\pi n(n+1)(n+2) a \frac{V}{T}
$$

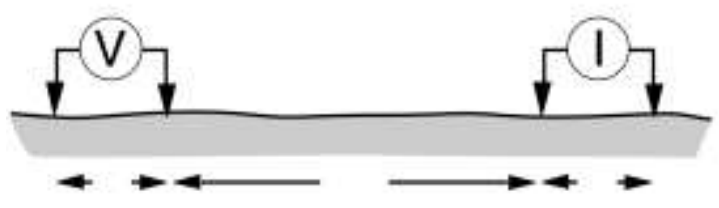

Gambar 1. Susunan elektroda pada konfigurasi dipole-dipole (Milsom, 2003)

Metode geolistrik konfigurasi dipoledipole (Gambar 2) merupakan salah satu konfigurasi yang populer karena pemisahan lengkap dari rangkaian arus dan tegangan mengurangi kerentanan terhadap noise induktif. Pada prinsipnya, semakin besar nilai n, semakin dalam penetrasi arus lintasan sampel (Gambar 3). Informasi perubahan kedalaman diperoleh dengan mengubah $\mathrm{n}$. Ketika dipole-dipole diperluas, semua elektroda dipindahkan dan kontribusi dari tubuh batuan dekat permukaan bervariasi dari setiap pembacaan. Hasil biasanya diplot dalam bentuk pseudo-sections (Milsom, 2003).

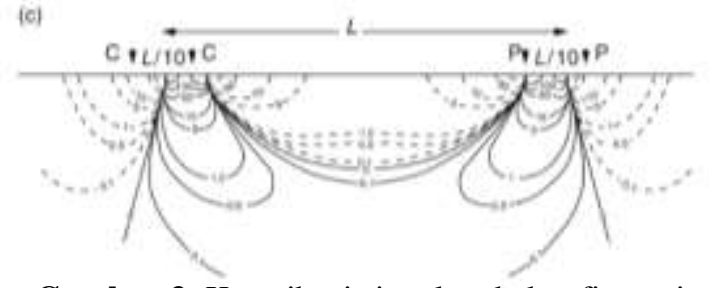

Gambar 3. Kontribusi sinyal pada konfigurasi dipole-dipole (Milsom, 2003).

Nilai resistivitas batuan merujuk pada tabel resistivitas batuan yang disusun oleh Loke (1999) dan Telford et al (1990) (tabel 2).

Tabel 2. Harga resistivitas berbagai batuan, mineral (Loke, 1999); * (Telford, Geldart, \& Sheriff, 1990)

\begin{tabular}{|c|c|}
\hline Material & $\begin{array}{l}\text { Resistivity } \\
\text { (Ohm.m) }\end{array}$ \\
\hline \multicolumn{2}{|l|}{ Igneous and } \\
\hline \multicolumn{2}{|l|}{ Metamorphic Rocks } \\
\hline Granite & $5 \times 10^{3}-10^{6}$ \\
\hline Basalt & $10^{3}-10^{6}$ \\
\hline Slate & $6 \times 10^{2}-4 \times 10^{7}$ \\
\hline Marble & $10^{2}-2,5 \times 10^{8}$ \\
\hline Quartzite & $10^{2}-2 \times 10^{8}$ \\
\hline \multicolumn{2}{|l|}{ Sedimetary Rocks } \\
\hline Sandstone & $\begin{array}{l}8-4 \times 10^{3} \\
200-8000^{*}\end{array}$ \\
\hline Shale & $20-2 \times 10^{3}$ \\
\hline Limestone & $50-4 \times 10^{2}$ \\
\hline Gravel & $100-600 *$ \\
\hline \multicolumn{2}{|l|}{ Soils and water } \\
\hline Clay & $1-100$ \\
\hline Alluvium & $10-800$ \\
\hline Groundwater & $10-100$ \\
\hline & $0,5-300 *$ \\
\hline Sea water & 0,2 \\
\hline
\end{tabular}

Faktor geometri konfigurasi ini diberikan oleh persamaan

$$
K=\pi n(n+1)(n+2) a
$$

Persamaan yang digunakan untuk menghitung tahanan jenis semu adalah:

$$
\rho_{a}=K \frac{V}{I}
$$

Pemukiman masyarakat di Kelurahan Kambo berada pada lereng bukit sehingga sangat berpotensi terjadinya longsor. 
Penelitian ini bertujuan untuk mengidentifikasi batuan bawah permukaan daerah longsor di Kelurahan Kambo berdasarkan data resistivitasnya. Manfaat dari penelitian ini sebagai langkah awal dalam mitigasi bencana longsor di kawasan pemukiman Kelurahan Kambo.

\section{Metode Penelitian}

Penelitian ini dilaksanakan di Kelurahan Kambo Kecamatan Mungkajang, Kota Palopo. Dalam penelitian ini, lokasi difokuskan di sepanjang jalan poros kelurahan yang menghubungkan Kelurahan Kambo dengan kelurahan sekitarnya.

\section{Pengumpulan Data}

Data dalam penelitian ini langsung diambil di lapangan. Data yang diambil berupa data deskripsi kemiringan lereng dan kejadian longsor di lokasi penelitian dan pengukuran geolistrik tahanan jenis. Ada pun tahapan pengumpulan data sebagai berikut:

1. Pembuatan Peta Kemiringan Lereng Kelurahan Kambo.

Peta kemiringan lereng lokasi penelitian dibuat dengan memanfaatkan data DEM SRTM resolusi $30 \mathrm{~m}$.

\section{Pemetaan Lokasi Longsor di Kelurahan} Kambo

Pemetaan lokasi longsor dilakukan di sepanjang jalan poros Kelurahan Kambo yang dibagi ke dalam tujuh stasiun pengamatan. Setiap stasiun pengamatan dicatat koordinatnya menggunakan Global Positioning System (GPS).

\section{Pengukuran Geolistrik Tahanan Jenis.}

Alat yang digunakan adalah seperangkat alat resistivitymeter tipe IPMGEO 4100. Konfigurasi yang digunakan adalah konfigurasi dipole-dipole dengan panjang bentangan $60 \mathrm{~m}$ dan jarak antar elektroda 5 $\mathrm{m}$.

\section{Pengolahan dan Analisis Data}

Pembuatan peta kemiringan lereng memanfaatkan perangkat lunak pengolah data SIG. Reklasifikasi kelas kemiringan lereng merujuk pada Tabel 1.

Pemetaan daerah longsor Kelurahan Kambo juga menggunakan perangkat lunak pemetaan. Data koordinat yang diperoleh hasil survey lapangan kemudian diplot. Hasil ini selanjutnya dideskripsikan sesuai dengan pengamatan lapangan.

Lintasan pengukuran geolistrik terletak pada lereng sisi jalan. Pada lokasi ini terdapat indikasi terjadinya longsor berupa terdapat retakan pada jalan. Data yang diperoleh berupa data potensial dan kuat arus yang mengalir dalam batuan. Untuk memperoleh tahanan jenis semu dihitung menggunakan Pers. (2). Selanjutnya penampang tahanan jenis diperoleh dari hasil inversi Res2Dinv.

\section{Hasil dan Pembahasan}

\section{Kemiringan Lereng Kambo}

Peta kemiringan lereng Kambo diperoleh dari pemanfaatan citra SRTM resolusi 30 m. Citra SRTM tersebut diproses menggunakan aplikasi pengolah SIG. Kemiringan lereng Kambo dibagi ke dalam lima kelas lereng berdasarkan Tabel 1. Hasil pengklasifikasian tersebut dapat dilihat dari Gambar 4.

Kemiringan lereng di Kelurahan Kambo umumnya Landai - Sangat Curam. Untuk daerah yang memiliki kemiringan lereng Curam $\left(13,5^{\circ}-25,5^{\circ}\right)$ menempati sekitar $25,7 \%$ daerah penelitian. Kemiringan lereng Sangat Curam $\left(>25,5^{\circ}\right)$ menempati daerah penelitian sekitar $0,5 \%$. Kemiringan lereng Landai $\left(5^{\circ}-7,5^{\circ}\right)$ menempati sekitar 21,4\% daerah penelitian. Kemiringan lereng Datar $\left(<5^{\circ}\right)$ menempati sekitar $4,8 \%$ daerah penelitian umumnya berada berada di bagian timur. 


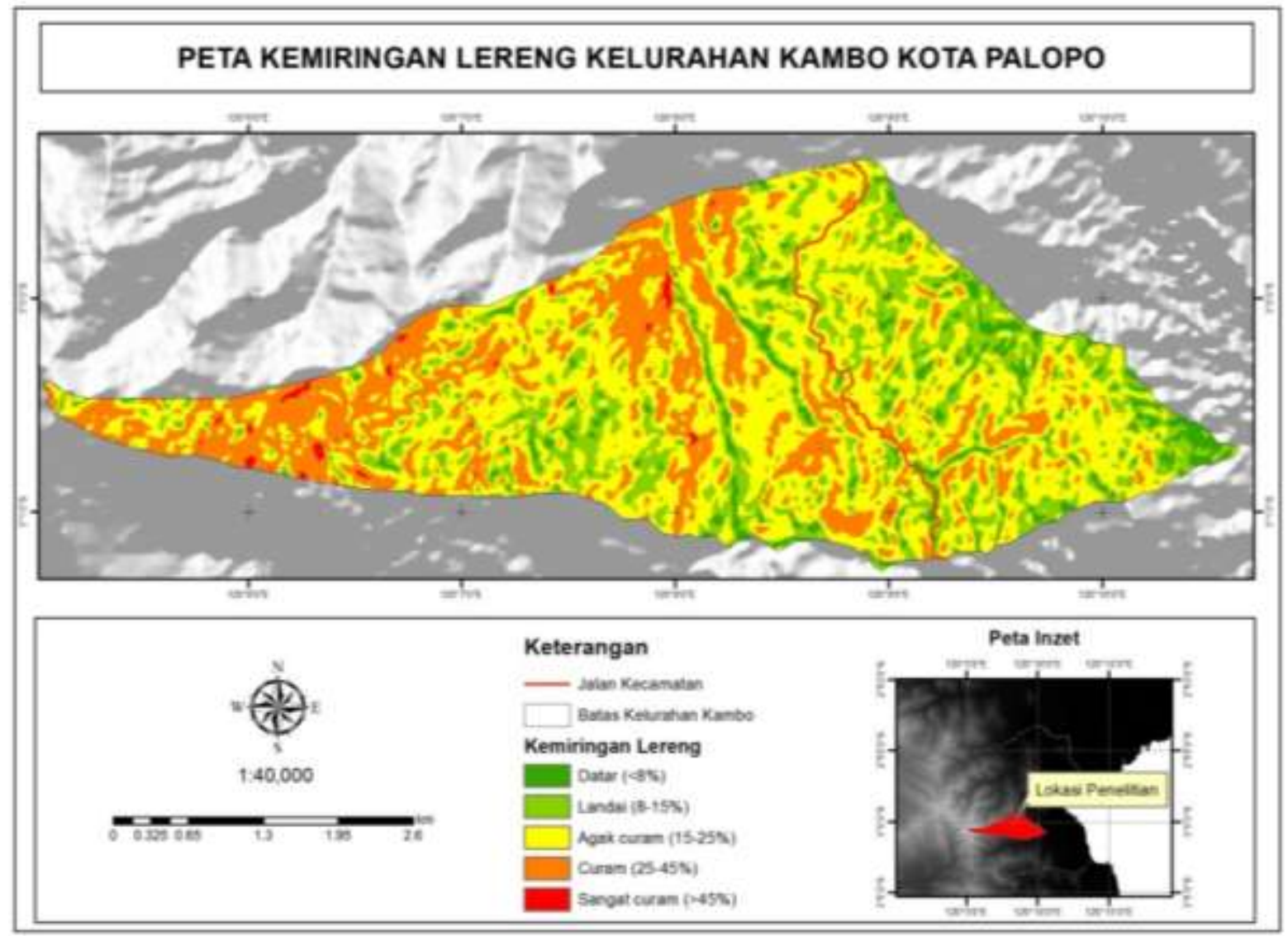

Gambar 4. Peta Kemiringan Lereng Kelurahan Kambo

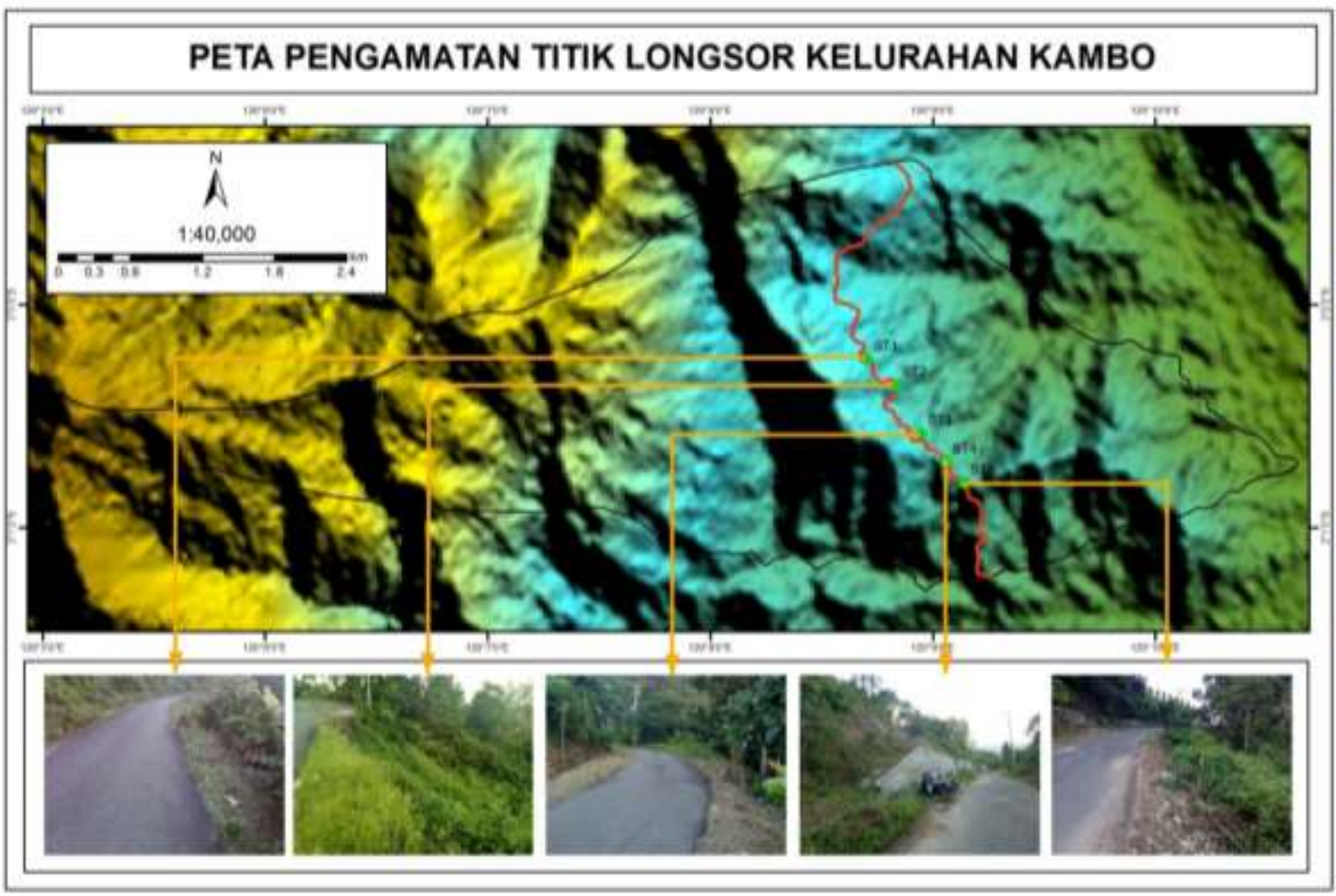

Gambar 5. Peta Pengamatan Titik Longsor Kelurahan Kambo

Sepanjang jalan poros Kelurahan Kambo yang merupakan lokasi survey memiliki kemiringan lereng Landai-Curam. Di sepanjang jalan ini merupakan kawasan pemukiman. Hasil pengamatan di bagian selatan telah terjadi beberapa longsor. 


\section{Titik Longsor Kelurahan Kambo}

Pengamatan titik longsor Kelurahan Kambo dilakukan di lima stasiun pengamatan (Gambar 5) yaitu ST1, ST2, ST3, ST4 dan ST5. Stasiun pengamatan ST1 terletak pada koordinat 300'14,598'S, $120^{\circ} 08^{\prime} 42,264^{\prime \prime}$ E. Pada titik ini terdapat longsoran berupa retakanretakan pada aspal. Stasiun pengamatan ST2 terletak pada koordinat $3^{\circ} 00^{\prime} 21,6^{\prime \prime}$, $120^{\circ} 8^{\prime} 50,1^{\prime \prime} \mathrm{E}$ merupakan titik longsor dengan jenis longsoran translasi. Stasiun pengamatan ST3 berada pada koordinat $3^{\circ} 00^{\prime} 42,234^{\prime \prime}$, $\quad 120^{\circ} 09^{\prime} 3,564^{\prime \prime} \mathrm{e}$ juga terdapat longsor berupa retakan tanah pada aspal. Stasiun pengamatan ST4 berada pada koordinat $\quad 3^{\circ} 00^{\prime} 47,988^{\prime \prime}$, $120^{\circ} 09^{\prime} 8,406^{\prime \prime} \mathrm{E}$ terdapat bekas longsoran yang telah diberi tembok penahan. Pada stasiun pengamatan ST5 terletak pada koordinat $3^{\circ} 00^{\prime} 47,988^{\prime}$ 'S, $120^{\circ} 9^{\prime} 8,406^{\prime \prime} \mathrm{E}$ juga terdapat longsoran berupa retakan tanah pada aspal.

Longsor yang terjadi di Kelurahan Kambo berupa longsor rayapan berupa rekahanrekahan pada tanah seperti yang terjadi di
ST1, ST3 dan ST5. Longsor ini bergerak lambat yang disebabkan oleh lalu lalang kendaraan.

\section{Penampang Tahanan Jenis batuan Penyusun Kambo}

Untuk memperoleh gambaran bawah permukaan di Kelurahan Kambo, maka dilakukan survey geofisika dengan menerapkan metode geolistrik. Dalam pengukuran geolistrik ini menggunakan konfigurasi dipole-dipole dengan panjang lintasan $60 \mathrm{~m}$, jarak antar elektroda terkecil $5 \mathrm{~m}$. Hasil pengukuran selanjutnya diolah dan diinversi menggunakan software Res2dinv menghasilkan penampang resistivitas batuan bawah permukaan seperti pada Gambar 6.

Berdasarkan gambar 6, nilai resistivitas batuan daerah penelitian berada pada rentang 9,5 - 2571 Ohm.m yang dibagi ke dalam dua lapisan batuan. Lapisan pertama memiliki nilai tahanan jenis 9,5 - 105 Ohm.m berada pada permukaan hingga kedalaman $10 \mathrm{~m}$. Lapisan ini merupakan

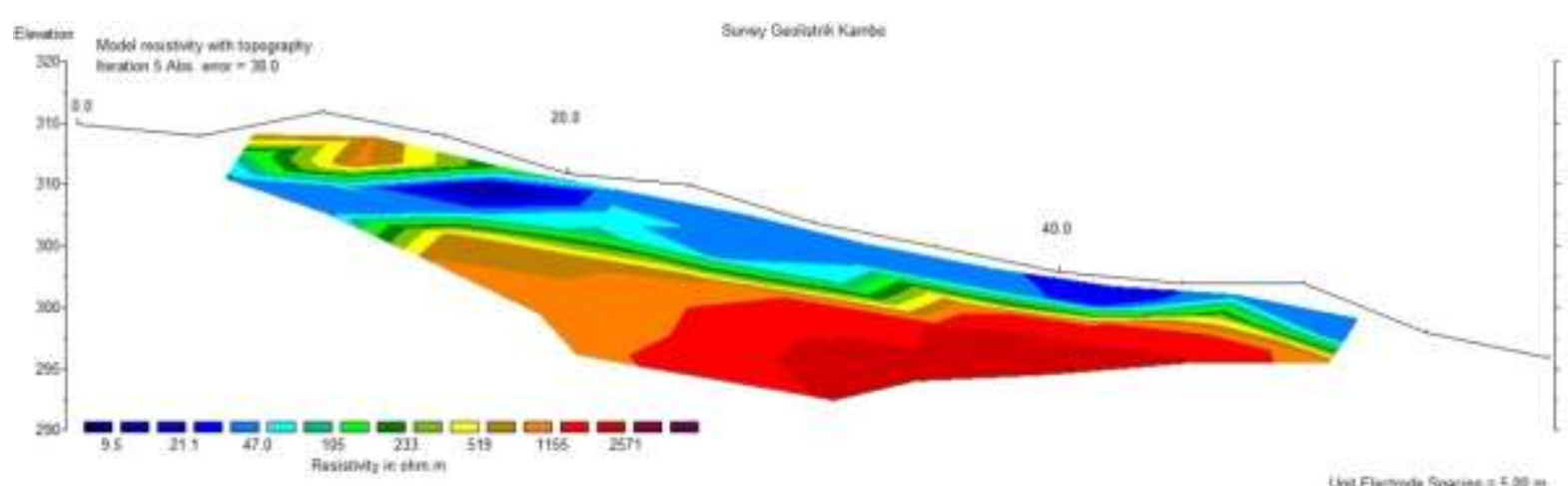

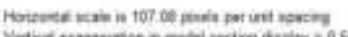

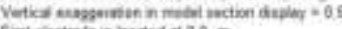
Pret wactinde in located at $0.9 \mathrm{~m}$

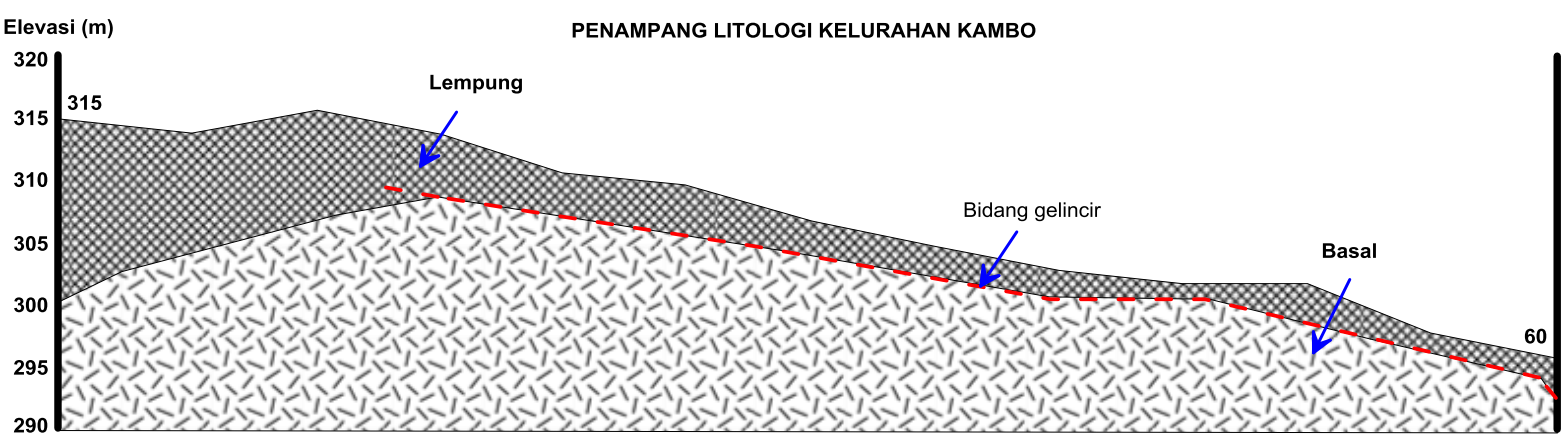

Gambar 6. Penampang Tahanan Jenis (atas), penampang litologi Kelurahan Kambo (bawah). 
lapisan batuan berupa lempung hasil pelapukan batuan. Penampakan lapangan berwarna cokelat. Lapisan di bawahnya merupakan lapisan batuan yang lebih keras (basal) yang memiliki nilai tahanan jenis 105 - 2571 Ohm.m. Batuan antara kedua lapisan batuan ini diindikasikan sebagai zona bidang gelincir longsor memiliki nilai tahanan jenis 233 Ohm.m (hijau tua-hijau muda).

Hasil penampang geolistrik mengungkapkan bahwa lapisan batuan Kelurahan Kambo terdiri atas lapisan tanah hasil pelapukan batuan basal dengan ketebalan 5-10 m berada di atas lapisan batuan yang lebih solid (basal). Kontak antara lapisan tanah bagian atas dan batuan di bawahnya berupa bidang gelincir yang terbentuk cukup rata. Longsor yang dihasilkan dari bentuk seperti ini adalah longsor tipe translasi.

\section{Kesimpulan}

Dari hasil dan pembahasan yang telah dilakukan maka dapat disimpulkan bahwa Pertama, Kelurahan Kambo memiliki kemiringan lereng datar-sangat curam dimana terdapat beberapa titik longsor berupa longsor rayapan dan translasi. Kedua, Batuan bawah permukaan terdiri dari lempung dengan nilai resistivitas 9,5105 Ohm.m berada pada kedalaman $10 \mathrm{~m}$ dan lapisan di bawahnya merupakan lapisan batuan yang lebih keras (batuan beku) yang memiliki nilai tahanan jenis 105 - 2571 Ohm.m. Batas antara kedua lapisan ini merupakan bidang gelincir longsor dengan nilai tahanan jenis 233 Ohm.m. Terakhir, Jenis longsor yang dihasilkan dari kondisi di Kelurahan Kambo adalah longsor tipe translasi.

\section{Ucapan Terima Kasih}

Ucapan terima kasih penulis ucapkan kepada seluruh pihak yang telah membantu dalam terlaksananya penelitian ini terkhusus kepada pihak Universitas
Cokroaminoto Palopo dalam hal ini Lembaga Penelitian dan Pengabdian Kepada Masyarakat (LPPM) yang telah membiayai penelitian ini melalui skema Hibah Penelitian Dosen Pemula tahun 2019.

\section{Daftar Pustaka}

Kementerian ESDM. 2017. Peta Prakiraan Wilayah Terjadinya Gerakan tanah pada Bulan Mei 2017 Provinsi Sulawesi Selatan. Jakarta: Pusat Vulkanologi dan Mitigasi Bencana Geologi, Kementerian ESDM.

Loke, M. H. 1999. Electrical Imaging Surveys for Environmental and Engineering Studies. Penang: Geotomo Software.

Manrulu, Rahma Hi., Nurfalaq, Aryadi. 2017. Studi Bidang Gelincir Sebagai Langkah Awal Mitigasi Bencana Longsor. Seminar Nasional 2017. Universitas Cokroaminoto Palopo.

Manrulu, R. H., \& Nurfalaq, A. 2018. An Identification of Landslide Potenstial Areas by Using The Shuttle Radar Topography Mission (SRTM) Images. 1st International Conference on Multidisciplinary Engineering (ICoMdEn). Lhokseumwe - Aceh, Indonesia: Universitas Malikussaleh Aceh.

Martono. 2004. Pengaruh Intensitas Hujan dan Kemiringan Lereng terhadap Laju Kehilangan Tanah pada Regosol Kelabu. Tesis, Program Pascasarjana Universitas Diponegoro Semarang.

Milsom, John. 2003. Field Geophysics The Geological Field Guide Series. London: JohnWiley \& Sons Ltd.

Padli, F., Jumardi, A., Busrah, Z., \& Asrun, B. (2017). Identifikasi Kemiringan Lereng di Kawasan Pemukiman Kecamatan Mungkajang Berbasis Geographic Information System. Prosiding 
SEMANTIK 2017 (pp. 7 - 17).

Kota Palopo: UNCP Press.

Pemerintah Kota Palopo. 2011. Laporan

Akhir RTRW Kota Palopo. Palopo:

Pemerintah Kota Palopo.

Redaksi Palopo Pos. 2016. Longsor di

Kambo, Satu rumah Ambruk.

[Online]. 27 October 2016.

[Accessed 19 February 2019].

Available from:

https://palopopos.fajar.co.id/2016/1

0/27/longsor-di-kambo-satu-

rumah-ambruk/

Syafri, Sriwahyuni Hi., Tilaar, Sonny.,

Sela, Rieneke L.E. 2015.

Identifikasi Kemiringan Lereng di

Kawasan Pemukiman Kota

Manado Berbasis SIG. Program

Studi Perencanaan Wilayah \& Kota

Universitas Sam Ratulangi

Manado.

Telford, W. M., Geldart, L. P., \& Sheriff, R. E. 1990. Applied Geophysics. New York: Cambridge University Press. 